\title{
HARMONIZATION (OR RATHER STANDARDIZATION) OF COOPERATIVE LAW IN THE OHADA ZONE: WHAT IS THE RESULT AFTER TEN YEARS OF IMPLEMENTATION OF THE UNIFORM ACT?
}

Willy Tadjudje

PhD Private Law

Lecturer University of Yaoundé II (Cameroun)

Associate lecturer University of Luxembourg

ORCID: 0000-0001-9340-7085

\begin{abstract}
The Uniform Act related cooperative societies (UA-COOP) is the main source of cooperative law in all the seventeen States parties to the OHADA founding Treaty. Ten years after its entry into force (2011-2021), the aim of this study is to assess the level of enforcement of this Act. More concretely, the aim is to compare the state of cooperative law at the time of the entry into force of the UA-COOP (2011) with the current situation (in 2021). Such a comparison should make it possible to assess the contribution of the UA-COOP to the development of cooperative law and strengthening of national cooperative movements in the OHADA zone.
\end{abstract}

KEYWORDS: OHADA, Cooperative law, Uniform Act, Standardization, Africa.

CLAVES ECONLIT / ECONLIT DESCRIPTORS: K1, K2, K4.

Cómo citar este artículo/How to cite this article: TADJUDJE, W.: "Harmonization (or rather Standardization) of Cooperative Law in the OHADA Zone: What is the Result after Ten Years of Implementation of the Uniform Act?", CIRIEC-España, Revista Jurídica de Economía Social y Cooperativa, nº 39, 2021, pp. 67-96. D0I: 10.7203/CIRIEC-JUR.39.21987 


\section{RESUMEN AMPLIO}

\section{LA ARMONIZACIÓN (O MÁS BIEN LA UNIFORMIZACIÓN) DEL DERECHO COOPERATIVO EN LA ZONA OHADA: ¿CUÁL ES EL RESULTADO TRAS DIEZ AÑOS DE APLICACIÓN DEL ACTO UNIFORME?}

Este artículo es un resumen de la investigación realizada por un equipo de investigadores. El objetivo era analizar la Ley Uniforme de Sociedades Cooperativas de la OHADA (AU-COOP) tras diez años de aplicación. El Acto Uniforme fue adoptado el 15 de diciembre de 2010 y entró en vigor el 15 de mayo de 2011 en todos los diecisiete Estados parte del Tratado OHADA. Esta Ley Uniforme pretende, por tanto, modernizar el derecho de las cooperativas, que estaba anclado en las leyes coloniales, en leyes inadecuadas que datan del período posterior a la independencia, o en leyes más recientes que permiten la autonomía e independencia de las cooperativas. La investigacion pretende analizar el nivel de implantación de AUSCO0P tras diez años de aplicación

En resumen, se pueden extraer dos ideas principales de las conclusiones y recomendaciones de los autores. Por un lado, el AU-COOP contiene debilidades e incoherencias que merecen ser corregidas durante una reforma. Por otra parte, el AU-COOP adolece de una falta de “comunión" con el entorno jurídico. De forma más sistemática, la cuestión de la falta de "comunión" con el entorno jurídico parece haber sido la principal causa de la escasa aplicación del AU-COOP, más allá de todas las incoherencias señaladas por los autores. La falta de "comunión" puede explicarse por una especie de "retirada" del derecho de la OHADA. Esta última parece estar "encerrada en sí misma" en ausencia de una sinergia positiva con las leyes sectoriales (son leyes que regulan sectores de actividad. Pueden ser nacionales. Ejemplo: Código de Minas, Ley de Farmacia, etc., o regional. Ejemplo 1: el Código CIMA -Conferencia Interafricana de Mercados de Seguros. Ejemplo 2 : Reglamentos de la CEMAC - Comunidad Económica y Monetaria de África Central o de la UEMOA -Unión Económica y Monetaria de África Occidental- sobre la microfinanciación, etc.) y las leyes transversales (leyes que regulan un aspecto global de la vida empresarial. Por ejemplo, el derecho fiscal, el derecho contable, el derecho de la competencia, el derecho laboral, el derecho de las ayudas estatales, etc. Algunos son nacionales y otros regionales).

Este "retroceso", en lo que respecta a las leyes sectoriales, se basa en el artículo 10 del Tratado OHADA, que establece que "los Actos Uniformes son directamente aplicables y vinculantes en los Estados Contratantes, no obstante cualquier disposición anterior o posterior de derecho interno en sentido contrario". Sin embargo, el AU-COOP es una ley general y, como tal, debe permitir que se adopten leyes especiales nacionales o regionales para completar su 
(pp. 67-96)

arquitectura según la regla specialia generalibus derogant, que significa que las leyes especiales derogan las leyes generales. Más concretamente, cuando dos leyes pueden aplicarse a una situación, una especial y otra general, la ley especial tiene preferencia. Dado que el derecho de la OHADA no admite la adopción de leyes especiales que puedan contener disposiciones contrarias a sus normas, es difícil conciliarlo con las leyes sectoriales que puedan intervenir en la vida de las cooperativas. Dado que el equilibrio clásico entre el derecho general y el especial no puede lograrse según la regla specialia generalibus derogant, esto da lugar a una especie de derecho de la OHADA “orientado hacia dentro" y, por tanto, a una falta de "comunión" con el entorno jurídico.

En esta perspectiva, el artículo 5 del AU-C00P, según el cual "las sociedades cooperativas funcionarán en todas las ramas de la actividad humana", ha sido especialmente problemático. De hecho, varias leyes sectoriales, tanto nacionales como regionales, no han admitido la forma cooperativa como forma jurídica autorizada para el ejercicio de la actividad que regulan. Además, algunas leyes sectoriales han admitido normas contrarias a las de AU-COOP. Los autores aportan ejemplos en los sectores financiero y sanitario.

En cuanto al "retroceso" de las leyes transversales, los autores subrayan que, en varios aspectos, estas leyes no tienen en cuenta las especificidades de la forma cooperativa. Estas leyes se adoptaron en su mayoría sobre la base del modelo de funcionamiento de las empresas comerciales, sin integrar a menudo las características distintivas de las cooperativas. Además, se han observado incoherencias entre los diferentes Actos Uniformes, con una especie de "aislamiento" del AU-COOP. Este último fue adoptado en 2010, años después de la entrada en vigor de las otras Leyes Uniformes, que fueron diseñadas sobre la base de la fisonomía de las sociedades comerciales.

A la vista de todo, nos parece que habría que prever un trabajo de "puesta en común" del derecho OHADA con las leyes sectoriales y transversales para facilitar la aplicación del AUCOOP. Además, más allá de esto, parece que no se ha hecho lo mínimo que se debería haber hecho. En realidad, la aplicación del AU-COOP parece haber sido un fracaso no tanto porque el contenido sea malo, sino sobre todo porque los Estados no se tomaron en serio su recepción. El verdadero problema reside en la formación y la sensibilización. Según un actore del sector cooperativo en la zone OHADA, "sería necesario planificar todo un programa de sensibilización y apropiación del AU-COOP, con los consiguientes recursos, para permitir que sus beneficiarios conozcan brevemente la OHADA; informar al público objetivo sobre los cambios introducidos por la AU-COOP; animar y apoyar a las cooperativas en la armonización de sus estatutos con las disposiciones de la AU-COOP; permitir que la autoridad encargada de llevar el registro de las cooperativas reciba formación para entender el AU-CO0P; actualizar los datos estadísticos básicos de las cooperativas (lo que justifica la informatización); armonizar el control de las cooperativas mediante la realización de auditorías". 
Dada su política de uniformización del derecho, que no parece dar frutos y que afecta a la aplicación coherente y eficaz del AU-COOP, nos parece que la OHADA debería avanzar hacia un enfoque mixto de armonización-uniformización. En efecto, si el AU-COOP sólo define en principio normas generales (derecho común), ello supone dejar implícitamente en manos de las autoridades nacionales o regionales el establecimiento de normas especiales (que deberían poder ser contrarias a sus normas más bien generales). Desde el punto de vista funcional, esta estrategia parece tanto más adecuada cuanto que las categorías específicas pueden variar de un Estado a otro.

PALABRAS CLAVE: OHADA, Derecho cooperativo, Ley uniforme, Uniformización, África. 
(pp. 67-96)

\section{SUMMARY}

Introduction. I. Cooperative law in the OHADA zone at the time of the entry into force of the UA-COOP. A. The reception of the UA-COOP. B. The main changes introduced by the UA-COOP. II. Cooperative law in the OHADA zone since the entry into force of the UACOOP. A. A low level of implementation of the UA-COOP. B. Difficulties in the application of the UA-COOP. Conclusion. References.

\section{Introduction}

This article follows and is in a way the summary of a collective reflection led by researchers to assess the $\mathrm{OHADA}^{1}$ Uniform Act related to cooperatives societies $(\mathrm{UA}-\mathrm{COOP})^{2}$.

Within the OHADA zone, the States have had various laws since independence. For the most part, the first laws, adopted in the aftermath of independence (mostly in 1960), established a close link between the State and cooperatives, the latter being an instrument in the hands of political power. Later laws (1990's) removed this link and established the autonomy of cooperatives as private enterprises ${ }^{3}$.

In 2010, after almost ten years of negotiation within the OHADA zone, a Uniform Act was adopted on December 15, 2010 and published on February 15, 2011 in the OHADA official journal (OHADA Uniform Act related to cooperative societies - UA-COOP). This Act replaces the national laws which are destined to disappear or, at least, to remain only as a complement to the Uniform $\mathrm{Act}^{4}$ (article 2 of

1. OHADA refers to the Organization for the Harmonization of Business Law in Africa. It is a legal integration organization created in 1993 with the aim of standardizing business law within its members (17 at the moment) through the adoption of Uniform Acts directly applicable at national level. To date, OHADA has already adopted ten Uniform Acts, the ninth of which deals with cooperative law. For more details on OHADA, vid. TADJUDJE, W. \& LABI, C.: "Business Ethics in the OHADA Zone: Uniform Law, Uniform Ethics?". In: An Anthology of Ethics (coord. FRENKEL, D.), Athens Institute for Education and Research (ATINER), Atenas, 2020, pp. 47-62. See also its website: https://www.ohada.org/en/

2. Vid. TADJUDJE, W. (coord.): Le droit des coopératives en Afrique. Réflections sur l'Acte uniforme de l'OHA$D A$, Éditions et Presses Universitaires de Reims (Épure), Reims, 2021. The book is available and can be freely downloaded online: https://library.oapen.org/handle/20.500.12657/50848

3. For more details regarding the history of cooperative law in Africa, vid. TADJUDJE, W.: "L'évolution historique du droit des sociétés coopératives en Afrique”. In: Droit des coopératives OHADA (coords. HIEZ, D. \& KENMOGNE SIMO, A.), Presses Universitaires d'Aix-Marseille (PUAM), Marsella, 2017, pp. 89-105.

4. The provisions of national cooperative laws apply as long as they are not contrary to those of the UA-COOP. 
the UA-COOP). The latter came into force ninety days after its publication, i.e. on 15 May 2011 (article 397 of the UA-COOP). It is expressly provided that existing cooperatives must adapt their by-laws within two years of this entry into force, in order to comply with its new provisions (article 396 of the UA-COOP), i.e. before May 15, 20135.

The objective of this Uniform Act is to modernize cooperative law ${ }^{6}$ in all the seventeen States parties ${ }^{7}$ to its founding Treaty. This justifies the alignment of the provisions of the UA-COOP with the ICA (International Cooperative Alliance) Statement on cooperative identity ${ }^{8}$.

The UA-COOP defines a cooperative as "an autonomous association of persons united voluntarily to meet their common economic, social and cultural needs and aspirations through a collectively owned and managed enterprise in which power is exercised democratically and in accordance with cooperative principles". This is a complete reiteration of the definition included in the ICA Statement. In addition, the OHADA legislator requires cooperatives to organize their activities and operate according to internationally recognized cooperative principles, with the obligation to incorporate these principles in the by-laws (article 6 of the UA-COOP) 9 .

In 2021 and after ten years of implementation of the UA-COOP, the question that can be asked is that of its effectiveness as the current legislation governing cooperatives in the OHADA zone. As mentioned above, a research has been conducted by a group of researchers to assess the level of implementation of the UA-COOP. This contribution is only a summary of the results. It should be pointed out that the former national legislations do not seem to have been evaluated to understand their strengths and weaknesses, prior to the introduction of the UA-COOP. Therefore, what could have justified the development of the UA-COOP? If the reasons for its

5. Vid. TADJUDJE, W.: Le droit des coopératives et des mutuelles dans l'espace OHADA, Éditions Larcier, Bruselas, 2015, pp. 74-79.

6. Vid. MÜNKNER, H.H.: "Strengths and weaknesses of the co-operative movement in west Africa - conditions for its development", Terre et progrès, $n^{\circ} 71,1987$, p. 16-18.

7. Benin, Burkina Faso, Cameroon, Central African Republic, Chad, Comoros, Congo, Democratic Republic of Congo, Ivory Coast, Gabon, Guinea, Guinea Bissau, Equatorial Guinea, Mali, Niger, Senegal and Togo.

8. For more details regarding the ICA Statement as well as its legal value, vid. HENRŸ, H.: "Public international cooperative law”. In: International Handbook of Cooperative Law (coords. CRACOGNA, D., FICI, A. \& HENRŸ, H.), Springer, Heidelberg, 2013, pp. 65-88.

9. Vid. HIEZ, D. \& TADJUDJE, W.: "Presentation of the new OHADA law on cooperatives", Revue International de l'économie sociale (RECMA), 2012.

Available online: http://www.recma.org/sites/default/files/new_ohada_cooperative_law.pdf 
(pp. 67-96)

development were legitimate, what is its added value in the light of its tenth year of implementation in the OHADA zone? ${ }^{10}$

In order to provide answers to this set of questions, we will begin by establishing the state of cooperative law in the OHADA zone at the time of the entry into force of the UA-COOP, before analysing the current situation.

\section{Cooperative law in the OHADA zone at the time of the entry into force of the UA-COOP}

The UA-COOP was adopted on $15^{\text {th }}$ December 2010 and entered into force on $15^{\text {th }}$ May 2011. It is worth looking at its reception, as well as the main changes it introduced.

\section{A. The reception of the UA-COOP}

The reception of the UA-COOP was perceived differently by the Governments and by the actors of the cooperative movement. According to CONAPROCAM ${ }^{11}$, "the entry into force of the Uniform Act was abrupt, since the organisations were not informed and sensitized after its adoption". On the other hand, Mr. DEUDJUI THEMA Alexis ${ }^{12}$ admits that "national experts participated and contributed to the drafting of the OHADA Uniform Act related to cooperative societies", even if he recognizes that the sensitization was weak.

The process of developing the UA-COOP took ten years ${ }^{13}$. In this respect, it is surprising that the stakeholders were not informed of the development process. This might suggest that they were not involved in the reflection.

10. It should be noted that OHADA's experience in standardizing cooperative law is the very first in Africa. A second one has been started in East Africa, but has not yet come into force. For more details, vid. TADJUDJE, W.: "The East African Community's Cooperative regulation", International Journal of Cooperative Law (IJCL), no 1, 2018, pp. 148-164.

11. National Confederation of Cocoa and Coffee Producers of Cameroon. The words are from KOUNDI Alexis Joseph, President. They were collected in July 2020.

12. It is Mr. DEDJUI THEMA Alexis. He was Deputy Director of Cooperative Action at the Ministry of Agriculture and Rural Development from 2011 to 2018. He is now retired. His comments were received in July 2020.

13. Vid. TADJUDJE, W.: Les conditions de l'effcacité des coopératives in Africa, Éditions Academia-EME, Louvain-La-Neuve, 2020, pp. 158-159. 
Despite a fairly long development period, the analysis of the interactions during the preparatory period suggests that the process of developing the UA-COOP was not sufficiently participatory, especially in its final phase. As a result, the cooperators, as well as all the actors involved in the cooperative movement in the different States, seem not to have been sufficiently involved. Yet it is their law, and they should at least have been informed of its elaboration and, in the best case, their opinion should have been taken into account. This process, which does not seem to have been sufficiently participatory has had repercussions on the receptivity of the OHADA law on cooperative societies, as we will see later ${ }^{14}$.

In our opinion, the process of developing the UA-COOP should have started with an assessment of the existing national laws. This evaluation would have highlighted their strengths and weaknesses. The positive elements would have been included in the UA-COOP as "good practices", while the negative aspects would have been corrected. Without such an analysis, one can rightly wonder on what basis the legislator drafted the UA-COOP, and moreover, without involving all stakeholders.

Moreover, the OHADA legislator did not offered education activities after the entry into force of the UA-COOP. One would have expected the States to do so in order to support cooperatives, insofar as they are important actors of sustainable development at the national level. When we compare the entry into force of the OHADA Uniform Acts in general, we can see that the UA-COOP may be the one that has received the least interest from the States. In our opinion, this can be explained by the idea that people have of cooperatives. They are still perceived as rural and village enterprises involving poor and destitute people. For these reasons, the UA-COOP has not aroused much interest in the business world, unlike other Uniform Acts which are mainly aimed at the capitalist world. It has been more taken into consideration by international NGOs, in the framework of rural development programmes ${ }^{15}$.

This perception should be changed, and this can only be done through education, training and awareness raising. Cooperatives run businesses, just like the company, with all the managerial requirements that go with $\mathrm{it}^{16}$. They can carry out activities in all branches of human life as recognized in article 5 of the UA-COOP. In many western countries, cooperatives have often played a decisive role in development.

\section{Idem.}

\section{Idem.}

16. The difference is that their management is based on their own ethics (cooperative principles and values), which is not the case in commercial companies. 
(pp. 67-96)

Consequently, African States would gain by reviewing their perception of cooperatives in order to position them as genuine actors in sustainable development ${ }^{17}$.

The entry into force of the UA-COOP should have been followed by an awareness raising programme. The aim should be to make people understand the content of the Act, in order to avoid differences in interpretation, knowing that it is a uniform law, i.e. a law that must be applied in the same way in all the OHADA States parties. On the whole, it can be noted that some provisions of the UA-COOP were subject to different interpretations from one State to another. For example, the issue of the authority in charge of the register was raised with acuity. According to article 70 of the UA-COOP, "the register of cooperative societies shall be kept at the local level by the administrative authority responsible for keeping the register. In each State party, the administrative authority responsible for keeping the register of cooperative societies shall be the deconcentrated or decentralized organ of the national authority in charge of territorial administration or the competent authority, to which the head office of the cooperative society is immediately attached". Given such a provision, one may wonder why the register is kept in Cameroon, Senegal, Central African Republic and Gabon, etc., by the Ministry of Agriculture. To take into account the importance of the innovations introduced by the UA-COOP, it would have been useful to organize a real awareness and training program.

\section{B. The main changes introduced by the UA-COOP}

By comparing the UA-COOP with national laws, some remarkable changes can be underlined. We will present the most important ones.

\section{The choice between the simplified cooperative (S-COOP) and the cooperative with a bord of directors (B-COOP)}

The UA-COOP provides for two forms of cooperatives, namely the simplified cooperative society (S-COOP) and the cooperative society with a board of directors $(\mathrm{B}-\mathrm{COOP})^{18}$. Although there is no provision to this effect, cooperatives must choose between these two forms. We questioned the reason for the distinction between two

17. Vid. TADJUDJE, W.: "Les enjeux de la définition de la société en droit OHADA", Revue de droit international et de droit comparé, n ${ }^{\circ}$ 95(2), 2018, pp. 283-300.

18. In terms of internal bodies, in S-COOPs, there is the management committee and the monitoring committee, while in B-COOPs there is the board of directors and the supervisory committee. 
forms of cooperatives. After investigation, it was revealed that it was to take into account the dynamics of groupings ${ }^{19}$ in some States $^{20}$.

Indeed, according to Mr. Idrissa Kéré, director of the legal department at the OHADA permanent secretariat until 2012, the issue of the integration of groupings in the UA-COOP had been considered during the preparatory period. The OHADA legislator had envisaged two forms of cooperatives, namely the S-COOP and the $\mathrm{B}-\mathrm{COOP}$, in order to take this reality into account. It provided for more flexible rules for S-COOPs, by analogy with the provisions governing groupings under national laws, while envisaging more rigid rules for B-COOPs. The objective was that groupings should be transformed into S-COOPs and classic cooperatives into B-COOPs. However, the OHADA legislator did not provide such a precision in the UA-COOP. Consequently, in the current state, classic cooperatives have the choice between the $\mathrm{S}$-COOP and the B-COOP and the groupings are not taken into account by the OHADA law and remain, in principle, governed by the national laws ${ }^{21}$.

\section{The introduction of an additional level in the cooperative movement structure}

Cooperatives are generally organized around umbrellas or apexes at three levels: union, federation and confederation. The first level is the union of cooperatives. It brings together two or more cooperatives with the same objectives for the management of their common interests (article 133 of the UA-COOP). Federations are at the second level. They bring together two or more unions, whether their objects are common or different, and aim to promote cooperation within the formed group, as well as to provide specific services to members (article 141 et seq. of the UA-COOP). Federations may even carry out economic activities in the interests of their members, subject to compliance with the principle of subsidiarity, i.e. on condition that these operations are not already carried out by affiliated unions or cooperatives (article 145 of the UA-COOP). At the third level are the confederations, made up of at least two federations of cooperatives. They have the same tasks as the federations, to which is

19. Vid. MÜNKNER, H.H.: "Possibilities and Problems of Transformation of Local Village Groups into Pre-Cooperatives", Third World Legal Studies, no 1(12), 1982, p. 174-192.

20. Namely Cameroon, Chad, Guinea and Burkina Faso. For more details, vid. CAIRE, G. \& TADJUDJE, W.: “ODD dans la zone OHADA, de l'outil coopératif au paradigme ESS”, Working Paper, United Nations Taskforce for Social and Solidarity Economy (UNTFSSE), Ginebra, 2019 (available online):

http://unsse.org/wp-content/uploads/2019/06/77_Caire_ODD-dans-la-zone-OHADA_Fr.pdf

21. For more details regarding the differences between S-COOP and B-COOP, vid. TADJUDJE, W.: Les conditions..., p. 72. 
(pp. 67-96)

added the task of disseminating and monitoring legal information (article 155 of the UA-COOP).

Unions, federations and confederations must, in principle, be constituted between cooperatives of the same State party to the OHADA Treaty. This is probably the reason why the OHADA legislator has set up another level of integration that can be transnational, so as not to limit the impetus to regroup the actors of the cooperative movement.

The setting up of cooperative networks of means and objectives is an innovation. These networks can be made up of unions, federations and confederations that do not necessarily share a common bond, with the objective of implementing, for a given period of time, all the means necessary to facilitate or develop the activity of their members, to improve the results of this activity, or to achieve objectives intended to promote the cooperative principles (article 160 of the UA-COOP).

Despite this innovation, it is surprising that no network has been registered so far. Yet the presence of such networks would have allowed the linking of national cooperative movements. In any case, as we will see later, the structuring of the cooperative movement remains rather weak.

\section{The notion of a common bond}

The UA-COOP introduces a very interesting concept: the "common bond". It is defined in article 8 as being "the objective element or criterion which cooperators have in common and on the basis of which they group together. It may, in particular, relate to a profession, an identity of purpose, activity or legal form". This concept is used in particular to limit the transfer of shares or to validate the introduction of new persons into the society (articles 217 and 380 of the UA-COOP). In concrete terms, a person can only join a cooperative if he or she shares the common bond defined in the by-laws by the initiators at the time of its creation. For example, if a cooperator dies and one of his heirs shares the common bond, he/she is eligible to replace his/ her progenitor within the cooperative, subject to compliance with the procedural requirements set out in the by-laws.

This concept is an important innovation in that it introduces more clarity into the process of joining a cooperative. With the entry into force of the UA-COOP, there is a basis of objectivity through which entries into the cooperative can be decided. It also has an impact on the functioning of the cooperative, in that it will now bring together people who have the same interest and who can work together to find common solutions to their problem. In practice, the cooperators have sometimes en- 
countered difficulties in defining the common bond. Since it is a concept with which they were not familiar, it was not always easy for them to handle.

\section{A great statutory freedom}

A comparison of the UA-COOP with national legislation shows that it gives a great freedom to the by-laws. It is up to the by-laws to determine the term of office of the directors and the election procedures, to determine the rate of return on shares, to indicate the amount to be reimbursed when members leave the cooperative, to specify the maximum number of shares that can be held by a single member, etc.

This broad competence given to the by-laws will certainly result in the undermining of the equality between members and, ipso facto, of the democratic principle to which the UA-COOP act declares to adhere. This could be the case if the by-laws allow, for example, a member to hold alone more than half of the share capital, or if the cooperative reimburses shares in real value, or if it remunerates these shares at a very high rate. This freedom can thus encourage the cooperative to implement practices that are not compatible with the cooperative ethics.

In practice, statutory freedom in itself is not a problem. It is the use made of it that can be worrying. If cooperative actors are well trained, they would make informed choices that correspond to their activity. On the other hand, in a context characterised by the absence of practical cooperative training, there is the risk of the emergence of aberrations. Actors not inhabited by the cooperative spirit may choose the cooperative form in order to take advantage of the benefits it offers, for individual purposes. The fact that statutory freedom is enshrined allows them to achieve their objective. In fact, the enshrinement of a broad statutory freedom should be accompanied by a major training and awareness campaign to help cooperators make the right choices in their operational functioning. It is regrettable that the OHADA legislator grants a large statutory freedom to cooperatives without training them beforehand, whereas this can encourage crooked actors to join the cooperative family, without sharing its operating mode, in order to simply take advantage of the benefits it offers.

\section{The non-accumulation of mandates}

The rules on non-accumulation of mandates are not as restrictive in S-COOPs as in B-COOPs. In S-COOPs, the chairperson of the management committee can be a member of a board of directors of a B-COOP but is not eligible for the position of 
(pp. 67-96)

chairperson of the board of directors. He/she can be a member of other management committees but is not eligible for the position of chairperson. On the other hand, in B-COOPs, directors may not belong to another board of directors of B-COOPs having their seat in the territory of the same State party (but may be members of management committees in other S-COOPs). Otherwise, they will have to choose one of the mandates and resign from the other one. The chairperson of the board of directors may not hold another mandate as chairperso of the board of directors or chairperson of the management committee in other cooperative societies located in the same State party. Likewise, as a director, he/she cannot be a member of another board of directors of a B-COOP having their registered office in the territory of the same State party. Otherwise, he/she will have to choose one of the mandates, and resign from the other one. However, he/she can be a member of a management committee without being able to be its chairperson.

\section{Cooperative law in the OHADA zone since the entry into force of the UA-COOP}

Looking at the cooperative movement in its current state, it can be seen that the level of implementation of the Uniform Act is still low. This is due to the persistence of numerous implementation problems.

\section{A. A low level of implementation of the UA-COOP}

Both Governments and cooperative members agree on the fact that the UACOOP has not been fully implemented. According to informal information gathered, less than $10 \%$ of cooperatives have been able to comply with the UA-COOP, apart from financial cooperatives. In Bangui, Central African Republic, during an information and sensitization activity of the cooperative movement organized on December 21, 2018, "the representative of the Food and Agriculture Organization of the United Nations (FAO) pointed out that the Central African Republic has not yet been able to fully engage in awareness raising of the UA-COOP in order to allow its appropriation, following the example of other States parties"22.

Cooperatives should be supported in their efforts to comply with the UA-COOP, either by the State, by apex organisations, or by a synergy of action between the State 
and the apex organisations. In practice, it has been noted that the State has resigned and that the umbrella organisations are unable to do so.

\section{The "resignation" of the State in supporting cooperatives}

The resignation of the State seems to be a reality. In Cameroon, the entry into force of the UA-COOP was surrounded by a series of constraints that were the responsibility of the State. Mr. DEUDJUI THEMA Alexis notes that when the UACOOP came into force, there was "a low enthusiasm of the actors who were not associated to the reform, an absence of awareness raising (several actors involved did not master the basis, the origin and the objective of the Uniform Act), an absence of financing to cover the expenses of education, information and training of the cooperatives, 3,000 in cooperatives to be sensitized and registered in the database $(10 \%$ were not touched in more than five years)."

According to the ILO (International Labour Organization), "Members should restrict the role of Government to a regulatory function for cooperatives aimed at:

1. the establishment of a policy and legal framework based on cooperative principles;

2. the establishment of an institutional framework for rapid and simplified registration of cooperatives;

3. the establishment of a policy and legal framework to promote a vertical cooperative structure that meets the needs of cooperative members;

4. the adoption of measures for the supervision of cooperatives equivalent to those applicable to other forms of enterprise" 23 .

There is no problem behind point. The law exists, that is the UA-COOP. On the other hand, the others seem to raise problems. The institutional framework for the rapid registration of cooperatives does not seem to be effective (point 2). Indeed, ten years after its adoption (2020), and while the UA-COOP provided for a transitional period of two years for the adaptation of the by-laws of pre-existing cooperatives, it turns out that in all the countries, few administrations and organisations have complied with these new rules. 
In the same perspective, the Cameroonian Government ${ }^{24}$ has, at a given time (2014-2016), and beyond the transitional period (2011-2013), suspended the registers, pending their compliance with the UA-COOP. This has led to a stagnation in the creation of cooperatives. As a result, the UA-COOP remains very little and poorly known by the actors, including by the officials in charge of promoting cooperatives. Registrations seem to have picked up since 2017, but there are still discrepancies and inconsistencies in the application of the rules. Regarding discrepancies, we can mention:

- It was revealed to us that officials in charge of the register would have refused, in certain localities, to register S-COOPs (imposing the B-COOP), or vice versa. Such an imposition is made without justification, and in an authoritarian manner.

- It has been observed that in some countries, officials require their physical presence at the constitutive general assembly of the cooperative as a condition for its validity. This participation is justified by the fact that they wish to ensure that the cooperative being set up meets the conditions laid down by the law.

- It has been noted that officials in some countries have introduced a requirement that the by-laws be approved by an expert prior to filing the application for registration. Such a requirement arises because the by-laws are sometimes poorly drafted. In this case, what is meant by "expert"? Through this requirement, many officials have taken the opportunity to "sell" model by-laws to promoters of cooperative initiatives.

With regard to inconsistencies, we can cite:

- The problem of the bank account: until now, cooperatives have always encountered difficulties in opening a bank account. Under the UA-COOP, the funds resulting from the payment of the shares are to be deposited immediately by the initiators or one of them, duly mandated for this purpose, in a bank, in a cooperative savings and credit society, in a postal cheque centre or in any other institution authorised by the law of the State party to receive such deposits, against a receipt in an account opened in the name of the cooperative society in formation (articles 213 and 274 of the UA-COOP). However, financial institutions are accustomed to opening bank accounts only in the name of entities with legal personality. The fact that financial institutions are reluctant to open accounts for

24. As well as other Governments, for example in Burkina Faso and Senegal. 
cooperatives in formation reflects the lack of consultation between Government authorities. A simple circular from the ministry in charge of finance would have been sufficient to explain this innovation, so that the financial institutions apply it in a concordant manner.

- Time limits for registration: in the registration procedure, the legislator has not provided for a time limit, unlike other legislators ${ }^{25}$. Article 77-2 of the UACOOP provides that "as soon as the application is in order, the administrative authority responsible for keeping the register of cooperative societies shall assign a registration number (...)". Such a provision may open the door to abuses by the officials in charge of promoting cooperatives.

Institutional problems are also visible in the Central African Republic. According to the Procedure Guidelines for actors in the mining sector $(2018)^{26}$, the Ministry of mining is in charge of the registration of mining cooperatives and delivers, at the same time, technical approval to operate in the mining sector, and registration to function as a cooperative. According to the UA-COOP, the mining authorities must limit themselves to issuing the authorizations and approvals necessary to legally carry out an activity in the mining sector, while the register of cooperative societies, provided for in the UA-COOP, deals with registration.

We will come back to point 3 a little later, when we analyse the role of umbrella organisations. With regard to point 4, the UA-COOP only provides for a system of indirect control. Article 178 (c, d and f) provides that the cooperative may be dissolved if it has not complied with the UA-COOP's provisions on the holding of general meetings for at least two consecutive years (this would imply that the cooperative's owners are not represented). The same sanction applies if the cooperative has failed, for a period of one year, to send to the competent authorities or institutions the notices and documents required by the UA-COOP. Finally, the same sanction is incurred when the cooperative is not organized or does not carry out transactions according to cooperative principles. At least indirectly, the UA-COOP organizes the control of the respect of the cooperative principles in cooperative societies, which helps to preserve their authenticity. However, it does not clearly specify the notices and documents referred to in Article 178 (c). It seems that it is these documents which would enable the registry authority to verify whether the cooperative has indeed respected the cooperative principles in its transactions or whether general 
(pp. 67-96)

meetings have been held. A global review of the UA-COOP allows to identify these notices and documents ${ }^{27}$.

On analysis, it is clear that these provisions do not seem sufficient to allow the register to exercise control over the respect of cooperative principles by cooperatives. "We currently have more than three thousand $(3,000)$ cooperative societies registered in the registers of cooperative societies and not controlled (which leads to a lack of statistical data available to the public)," underlines Mr. DEUDJUI THEMA Alexis. Contrary to these provisions of the UA-COOP, article 58 of the Cameroonian law of 1992, governing cooperatives and common initiative groups (CIGs) provides in its paragraph 1, that "the board of directors of any cooperative society must send to the service of the register where it is registered, within a period of two (2) months from the date of holding of the annual general assembly, the copy of the documents below, as approved by the said assembly: the annual activity report; the balance sheet, its annexes as well as the operating account; the report(s) of the auditor; the resolutions whose publicity is compulsory, in particular appointments or dismissals, as well as amendments to the by-laws; the minutes of the deliberation of the board of directors appointing the members of the credit committee for savings and credit cooperatives;

27. - Any decision to change the registered office must be notified in the register of cooperative societies (article 24 of the UA-COOP);

- The following are automatically entered in the register of cooperative societies: decisions taken in individual bankruptcy proceedings or in collective proceedings for the discharge of liabilities; decisions pronouncing patrimonial sanctions against directors; decisions of rehabilitation or amnesty measures removing disqualifications or prohibitions (article 73 of the UA-SCOOP);

- In case of transfer of the registered office of a cooperative society, the society concerned must request its deletion from the register of cooperative societies in whose jurisdiction it was registered and request a new registration in the register in whose jurisdiction the registered office is transferred, after verification, by this authority, of the effective deletion of the previous registration (Article 79 of the UA-COOP);

- If the situation of the cooperative society subsequently undergoes changes that require the correction or the addition of the information entered in the register of cooperative societies, the cooperative society must formulate, within thirty days of this change, an application for a corrective or additional entry. Any modification concerning in particular the by-laws of the cooperative society must be mentioned in the register of cooperative societies (article 80 of the UA-COOP);

- The appointment, dismissal or resignation of the directors must be published in the register of cooperative societies within one month (article $98 \mathrm{UA}-\mathrm{COOP}$ );

- The transformation becomes opposable to persons other than the cooperative members only after an amending entry in the register of cooperative societies (article 169 of the UA-COOP).

- The dissolution of the cooperative society has no effect on persons other than the cooperative members until it is entered in the register of cooperative societies (article 180 of the UA-COOP);

- The appointment of directors must be published in the register of cooperative societies (article 302 of the UA-COOP);

- The resignation or dismissal of a director must be published in the register of cooperative societies (Article 307 of the UA-COOP), etc. 
the information modalities provided for in paragraph 1 shall apply to the resolutions of any other general meeting whose publicity is compulsory."

As provided for in Article 61 (2) of the same law, where the documents referred to are not filed with the registry service within the prescribed time limit, a notice of default is notified by the latter to the president of the cooperative, for information of the next general meeting. In case of recurrence in the following year, the cooperative is liable to be dissolved. According to article 70 (paragraph 1), the dissolution of a cooperative is pronounced by the administrative authority in charge of the register, among other things, in case of failure to file the documents whose publication is compulsory, and this for two consecutive financial years.

This provision of the 1992 law in Cameroon seems clearer and more precise than the rules contained in the UA-COOP concerning the exercise, by the register of cooperatives, of a control function over the application of the cooperative principles. Through the documents required by article 61 (1) of this Cameroonian law, one realizes that the authority in charge of the register has sufficient elements to control the respect of democratic principles as well as economic principles. The annual activity report, the balance sheet, its annexes as well as the operating account and the report(s) of the auditor allow for the verification of the respect of the rules related to the constitution of reserves, the management of surpluses, as well as the other economic principles of cooperatives, particularly the distribution of dividends in proportion to the work accomplished, and not according to the number of shares held. Similarly, the resolutions that must be made public, in particular appointments or dismissals, as well as amendments to the articles of association; the minutes of the deliberations of the board of directors appointing the members of the credit committee for savings and credit cooperatives, would make it possible to measure the application of the "one person-one vote" rule, as well as compliance with all the democratic principles of cooperatives, in particular the equal treatment of cooperative members and the effectiveness of the holding of general meetings.

In view of the scattered and incomplete nature of the UA-COOP's rules on the control of the respect of cooperative principles in cooperatives, it can be argued that the Cameroonian law would remain applicable to cooperatives in this country, as long as it is not contrary to the rules defined by the UA-COOP, in accordance with the provisions of article 10 of the Treaty establishing the OHADA. However, what about countries that have not provided for such a control system in their national laws? At this level, there is a real problem. This would be evidence that the UACOOP had been drawn up without taking into account developments and opinions in the various States. The ideal would have been to try to reconcile national particularities in order to reach a consensus on the final text. 
(pp. 67-96)

\section{The inability of umbrella organisations to support cooperatives}

The cooperative movement is weakly structured and this does not allow the umbrella organisations to fully exercise their missions. In the context of the proper functioning of cooperatives, a preliminary challenge concerns the structuring of the cooperative movement. This is perhaps what justified the addition of a fourth level of the cooperative pyramid with the institution of cooperative networks of means and objectives. In fact, it is appropriate that it is structured in such a way that there is a single organization at the national level that represents the entire cooperative movement of the country in question. For example, according to article 32 of the Malagasy cooperative Act 1999, at the national level, the federations of cooperatives can group together in a confederation, which is the only national umbrella structure of the cooperative movement. However, the AU-COOP admits the possibility of a diversity of national confederations. After a review of article 155 of the UA-COOP, it looks like the UA-COOP requires each State party to set up a single national confederation of cooperatives. This article provides that in addition to the missions provided for in articles 144 to 146, the confederation has the following missions: to maintain a permanent and adequate campaign for awareness raising of this Uniform Act and other standards to which it refers; to guarantee a continuous monitoring of the evolution of the cooperative legislation; to defend the interests of its members at the national and international levels.

The idea of having a single confederation is justified by a practical argument. If cooperatives are not organised, they will not have an interlocutor capable of defending their interests at national or international level. In this case, public-private dialogue cannot be effective. Operating without serious national coordination, the cooperative movement may find it difficult to dialogue effectively with the Government to make the voice of cooperatives heard. This is what is observed in most OHADA State parties. In some of them, especially those in Central Africa, national organizations have been set up in a top-down manner, and therefore without any legitimacy ${ }^{28}$.

In the absence of real legitimacy, umbrella organizations suffer from a certain fragility. "In most cases, the hasty constitution of federative structures seems to be one of the main causes of internal conflicts in farmers' organizations. Indeed, observation of the process of creating umbrella structures shows that sometimes less than a year elapses between the idea of creating the organization, carried by a small

28. Vid. ACHANCHO, V.: Le rôle des organisations paysannes dans la professionnalisation de l'agriculture en Afrique Subsaharienne : le cas du Cameroun [PhD thesis, $\mathrm{PhD}$ thesis, Université Paris-Saclay], AgroParisTech, Paris, 2012, p. 320. 
number of leaders (the hard core), and the mobilization of the other organizations to form the movement. In this context, the process of participation necessary to clarify the stakes, the project defended by the organisation and its operating mechanisms does not give the other members enough time to appropriate the organisation that is being set up. Several members, even though they are considered to be founding members, adopt opportunistic attitudes and become 'followers' at this point, the main thing being to join the umbrella structure so as not to lose the advantages that could be derived from it at a later date" 29 .

Regarding the role of umbrella organizations, African cooperatives are not only weakly structured. They are also under-represented in the various forums where their voices should normally be heard. These include legislative processes and Government actions. In some countries, it has been noted that cooperative laws and land reforms have been adopted without proper consultation of cooperative actors. The same is true of Government actions taken without prior information of the cooperative movements. As a result, there is a risk that rules contrary to the needs and interests of cooperatives will be applied.

According to the above-mentioned ILO recommendation, it is up to the Government to establish a legal and institutional framework that is conducive to the development of cooperatives. In Madagascar, for example, the Government has played its part by establishing the national confederation as the sole representative of the cooperative movement, through a legal provision. On the other hand, the UA-COOP did not do so. In addition to the Government's will, a certain maturity of the cooperative actors is also needed ${ }^{30}$.

The absence of a national confederation as the sole representative of the national cooperative movement is due to cultural and socio-anthropological difficulties. Indeed, in most cases, the cooperative movements remain relatively weak either politically or financially. This can be explained by various reasons. It may be ignorance, and therefore lack of training. The cooperative is a place of emancipation and this is why training is a principle of its functioning. But this training is lacking, due to a lack of human and financial resources. It can also be a question of leadership quarrels. Everyone wants to be the president of the confederation and, in the end,

29. Idem, p. 321.

30. In Madagascar, despite the legal and institutional foundations laid by the cooperative act, the country does not yet have a national confederation. In the meantime, the State continues to exercise, on a transitional basis, all the functions devoted to the confederation by the cooperative act. For more details, vid. TADJUDJE, W.: "Les coopératives à Madagascar : quel équilibre entre attributions de l'État et développement du mouvement?", Révue Internationale de l'economie sociale (RECMA), n 351, 2019, pp. 101-113. 
(pp. 67-96)

the creation project ends up not being carried out. Finally, there may be a lack of financial resources to mobilise actors or to operate the new structure ${ }^{31}$.

Although they are weakly organised, umbrella organisations, particularly the confederations, do not seem capable of fulfilling their missions. Article 155 of the UA-COOP provides that the confederation has as its missions, among others, "to maintain a permanent and adequate campaign of awareness raising of the present Uniform Act and other standards to which it refers; to guarantee a continuous follow-up of the evolution of the cooperative legislation; to defend at the national and international levels the interests of its members". If we limit ourselves to the first element, namely "to maintain a permanent and adequate campaign for awareness raising of this Uniform Act and the other standards to which it refers", it goes without saying that they have failed insofar as they cannot popularise an act that they do not understand from the outset. Most authors acknowledge that the lack of cooperative education has been one of the major obstacles to the development of cooperatives in Africa $^{32}$. The low level of participation of cooperators in cooperative life is linked to insufficient education, awareness and information that does not allow for the development of a cooperative conscience among individuals ${ }^{33}$.

\section{B. Difficulties in the application of the UA-COOP}

Beyond the content of the UA-COOP, which contains provisions that are sometimes inconsistent, in addition to a context characterized by the scarcity of training in cooperative law, other circumstances affect the life of cooperatives. These circumstances can further complicate the applicability of the rules contained in the UACOOP.

\section{The isolation and the generality of the UA-COOP}

The UA-COOP seems to be isolated from the rest of the OHADA business law. Indeed, "despite the adoption of a UA related to cooperative law, this legal form of

31. Vid. BONTIANTI, A.: "Mouvement coopératif et organisation du monde rural au Niger : bilan, perspectives et propositions pour l'avenir", Les Cahiers d'Outre-Mer, n' 221, 2003, pp. 103-118.

32. For example, vid. TADJUDJE, W.: "L'accès durable des paysans à la terre : quel peut être l'apport des coopératives à la lutte contre l'accaparement des terres en Afrique ? ", Revue des mutations en Afrique, no 1(1), 2015, pp. 135-156.

33. Vid. TADJUDJE, W.: Les conditions..., pp. 187-188. 
organization remains marginalized and little taken into consideration by the legislator. (...) One has the impression that the UA of 2010 relating to the law of cooperative societies has remained an isolated act from the others, whereas the goal of the OHADA legislator is to produce a homogeneous business law adapted to the economies of the African States"34. This isolation is reflected in the incompatibility between the UA-COOP's rules and those of most of the other Uniform Acts, which correspond more to the features and characteristics of commercial companies. For example, the OHADA accounting law was modelled on the physiognomy of commercial companies without taking into account cooperative societies, although it mentions them. This incompatibility can also be observed when comparing the UACOOP with the business law standards produced by other community legislators. For example, while Article 5 of the UA-COOP states that cooperatives may carry out activities in all branches of human life, the CIMA $^{35}$ Insurance Code limits the exercise of insurance activities to public limited companies and micro-insurance activities to public limited companies and mutual societies. If cooperatives are excluded, there is an incompatibility between the two legislations.

In addition to being isolated, the OHADA legislator has chosen a general approach. The UA-COOP does not define specific rules according to activities. In view of this choice, it seems that the OHADA law is moving away from the mechanism of legal standardization towards a mixed harmonization-uniformity approach. Indeed, if the UA-COOP defines in principle only general rules, it is to leave implicitly to the national authorities the competence to set special rules. From a functional point of view, this strategy seems all the more appropriate since the specific categories may vary from one State to another. However, it is contrary to the will of the Organization to establish a uniform law applicable the same way in all its States parties ${ }^{36}$.

Prior to the UA-COOP, the savings and credit cooperative was almost the only special category of cooperative provided for in national or Community legislation. The UA-COOP did not deal with the relevant rules and explicitly refers to these national or Community laws ${ }^{37}$. A problem of concordance arises. These national or Community laws, as special laws, have been designed in harmony with national law.

34. Vid. TADJUDJE, W.: “Les enjeux...”, pp. 283-300.

35. CIMA stands for Conférence interafricaine des marchés de l'assurance, in English, Inter-African Conference on Insurance Markets. It is an African intergovernmental organization grouping 14 West and Central African countries, all members of OHADA. For more details see its website: https://cima-afrique.org/?lang=en

36. Vid. KAMDEM, I.F.: "Harmonisation, unification et uniformisation. Plaidoyer pour un discours affiné sur les moyens d'intégration juridique", Revue juridique Thémis (RJTUM), no 43(3), 2009, pp. 605-649.

37. Vid. TADJUDJE, W.: Le droit..., pp. 74-79. 
(pp. 67-96)

It is not obvious that their current connection to the OHADA law works harmoniously, as the two set of laws may not share the same legal logic. This difficulty will not be encountered in the other cooperative sectors which are still under construction and whose rules will be drawn up directly and in accordance with the OHADA law ${ }^{38}$.

\section{The low access of cooperatives to sources of funding}

It is generally very difficult for new cooperatives to raise the capital needed to launch the first operations ${ }^{39}$. Members' contributions are not always sufficient to provide all the services required to meet the needs and aspirations expressed by the members. Financial support, especially from the State, can be useful at such a time. In practice, especially in Cameroon, the State has taken the habit of granting subsidies to cooperatives without conditions, which has encouraged actors to create cooperatives simply to benefit from this aid. Such a system is not sustainable and contributes to the proliferation of non-viable cooperatives that subsist only on State support. These cooperatives therefore remain "on life support" until the end of the aid cycle ${ }^{40}$.

In order to treat cooperatives as real businesses with viable socio-economic projects, the State could proceed in another way to limit the creation of "false" cooperatives. Instead of subsidies, the State can grant loans to cooperatives at zero or reduced rates. In order not to limit the contribution of members who might rely solely on the loan that the State might grant, it is important to set ratios. For example, setting a ratio between the financial assistance in the form of a loan provided by the Government and the members' contributions so that the amount of a loan does not exceed the value of the capital paid in by the members ${ }^{41}$.

However, the loan should not be open to all cooperatives, and there should be conditions to be fulfilled to that effect, including undertaking activities in underserved areas, providing services not well covered in the market, undertaking not to pay interest on shares or patronage refunds to members for the duration of the loan, limiting exit rights until the loan received from the Government is fully amortized, etc ${ }^{42}$.

38. Vid. BABATUNDE, F:: "Towards the harmonisation of laws in Africa: is OHADA the way to go?", The Comparative and International Law Journal of Southern Africa, no 42(3), 2009, pp. 309-322.

39. Vid. TADJUDJE, W.: Les conditions..., pp. 120-130.

40. Idem.

41. Idem.

42. Vid. MÜNKNER, H.H.: "La loi coopérative, instrument de promotion des coopératives par l'Etat", Informations coopératives, $\mathrm{n}^{\circ} 1,1973$, pp. 27-43. 
In addition to the conditions, the Government could specify the use of the loan, so that it could be useful for the cooperative. This could be, for example, the costs of training members, or the salaries of qualified managers for a certain period of time. However, the conditions put forward by the Government for the granting of loans must not undermine the autonomy and independence of cooperatives. Similarly, the loans in question may be granted within the framework of the services offered by cooperative development funds, ideally set up in collaboration between the State and the national confederation of cooperatives ${ }^{43}$.

\section{The non-existence of audit rules}

The governance of cooperatives is weak, which justifies their inefficiency. The legislator could have put in place mechanisms, such as audit ${ }^{44}$. Indeed, in cooperatives, many financial malpractices are noted, without the members having sufficient means of pressure or control. The audit is a control, investigation or verification operation carried out by a competent and impartial agent. The audit makes it possible to carry out an evaluation of various aspects of a business. The audit is perceived as a tool for continuous improvement of the businessperformance, insofar as it allows an assessment of the current situation, in order to identify weak points or non-compliance with the regulations. Such an assessment gives the business the opportunity to correct malfunctions or to introduce regularisations.

Cooperative audit may cover financial and organizational control. With regard to financial audit, the East African Community Cooperative Societies Bill ${ }^{45}$, in Article 35 , provides that the competent authority should, at least once a year, audit or cause to be audited by a person appointed by it, the accounts of any cooperative society. The financial audit in question must include an examination and verification of the debts, cash, balance, securities, assets and liabilities. As for the organizational audit, it is also conducted by the competent authority or a person assigned by it. The organi-

\section{Idem.}

44. Vid. MÜNKNER, H.H.: "Cooperative audit". In: Principles of European Cooperative law (coords. FAJARDO GARCÍA, I.G., FICI, A., HENRŸ, H., HIEZ, D., MEIRA, D., MÜNKNER, H.H. \& SNAITH, I.), Intersentia, Cambridge, 2017, pp. 112-113.

45. Vid. TADJUDJE, W.: "Standardization of Cooperative law in Africa : A Comparative Analysis Between the OHADA Act Related to Cooperative Societies and the East Africa Community's Cooperative Societies Bill”, International Journal of Cooperative Law (IJCL), n 3, 2020, pp. 31-45. 
(pp. 67-96)

zational audit involves an inspection of the organization, the execution of the work, the documents and the financial situation ${ }^{46}$.

Usually, a financial or organizational audit is required when a request for inspection is made by a majority of the members of the board of directors, the supervisory committee or the general assembly, or at least one third of the total number of members of the cooperative society (Article 36 of the East African Community Cooperative Societies Bill). The purpose of the audit, whether financial or organizational, is to identify managerial malfunctions and to provide for sanctions. This can involve any person who is or was responsible for the management of a cooperative, or who is or was an officer or employee of a cooperative. During the audit or inspection, the persons concerned may be sanctioned if they are found to have made a payment contrary to the cooperative's statutes or regulations. They may also be sanctioned for having caused damage to the company's assets, in particular by breach of trust, voluntarily or by negligence. Finally, they can be sanctioned for having misappropriated the cooperative's property ${ }^{47}$.

Where a person is found liable, the competent authority receiving the report must give the person concerned the opportunity to present his defence within 15 days. In addition, the competent authority must require the person who has been found responsible for the misappropriation of the funds or property of a cooperative society to return the property or repay the funds with interest, including compensation and damages. In order to do so, the authority shall take appropriate legal measures (Article 37 of the East African Community Cooperative Societies Bill) ${ }^{48}$.

The audit can play a dual role ${ }^{49}$. On the one hand, the authority in charge of the register is not an expert on cooperative action and it is in this context that audit plays an essential role. Indeed, the control exercised over cooperative organizations should in principle be carried out on the basis of audit reports drawn up by independent entities (such as auditors for example). On the other hand, the audit allows the cooperative to identify and solve malfunctions quickly ${ }^{50}$.

Despite the silence of the OHADA legislator regarding the audit and in view of its importance in the governance, cooperative organizations can organize similar services themselves, particularly in the framework of the activities of umbrella organ-

46. Vid. TADJUDJE, W.: “Les coopératives...”, pp. 101-113.

47. Idem.

48. Idem.

49. Vid. MÜNKNER, H.H.: “Cooperative...”, pp. 112-113.

50. Idem. 
izations. However, the OHADA law has instituted management expertise. Under the terms of article 120 of the UA-COOP, cooperative members may, provided that they represent at least $25 \%$ of the members of the cooperative society, by grouping themselves in the form they deem appropriate, request the president of the competent court of the registered office to appoint one or more experts to present a report on one or more management operations. Where the request is granted, the court shall determine the scope of the mission and the powers of the experts. The fees of the experts shall be borne by the cooperative. The report shall be addressed to the applicant and to the management or administrative organs of the cooperative.

\section{Conclusion}

The implementation of the UA-COOP seems to have been a failure not so much because the content is bad, but mainly because the reception was not taken seriously by the States. As Mr. DEUDJUI THEMA Alexis acknowledges, the real problem lies in training and awareness-raising. According to him, "it would be necessary to plan a whole programme of awareness and appropriation of the UA-COOP, with consequent resources, in order to allow its beneficiaries to know briefly the OHADA; to inform the target public on the changes brought by the UA-COOP; to encourage and support cooperatives in the harmonization of their by-laws with the provisions of the UA-COOP; to enable the authority in charge of keeping the register of cooperatives to be trained in order to understand the UA-COOP; to update the basic statistical data on cooperatives (which justifies computerization); to harmonize the control of cooperatives by conducting audits".

The lack of awareness and effective implementation of the UA-COOP has consequences, including the unavailability of data on cooperatives in the national business file, the gradual reduction in the number of registrations over the years, and the low level of interest for the cooperative business legal form.

Even if the UA-COOP has not yet been fully implemented due to deficits in implementation, we cannot help but notice weaknesses in its content. In case of reform, one point of attention is the prior and complete evaluation of the UA-COOP against the cooperative principles and values. It should also be compared with previous national laws, as well as other laws around the world. As we have seen, the OHADA legislator could have been inspired by national experiences such as the cooperative control mechanism under the 1992 Cameroonian law. Instead, it has instituted an incoherent mechanism of control of cooperatives. The reference to other laws could 
(pp. 67-96)

help to understand the interest of instituting a national confederation as the sole representative of the cooperative movement of the States, or the merits of the audit.

Whatever options are taken, an important place should be given to education. It should be effective not only in the teaching environment, in order to allow the new generations to appropriate the cooperative ethic. It should especially be effective in the cooperative networks. It is important that the national confederation of cooperatives becomes autonomous and solidified to the point of putting in place all the tools to support cooperatives, with the help of the State. This would include a training centre, a development fund, a conflict management centre, etc ${ }^{51}$. 


\section{References}

ACHANCHO, V.: Le rôle des organisations paysannes dans la professionnalisation de l'agriculture en Afrique Subsaharienne : le cas du Cameroun [PhD thesis, Université Paris-Saclay], AgroParisTech, París, 2012.

https://pastel.archives-ouvertes.fr/pastel-00935522

BABATUNDE, F.: "Towards the harmonisation of laws in Africa: is OHADA the way to go?", The Comparative and International Law Journal of Southern Africa, $\mathrm{n}^{\circ}$ 42(3), 2009, pp. 309-322. https://www.jstor.org/stable/23253105

BONTIANTI, A.: "Mouvement coopératif et organisation du monde rural au Niger: bilan, perspectives et propositions pour l'avenir", Les Cahiers d'Outre-Mer, n ${ }^{\circ}$ 221, 2003, pp. 103-118. DOI: https://doi.org/10.4000/com.932

CAIRE, G. \& TADJUDJE W.: "ODD dans la zone OHADA, de l'outil coopératif au paradigme ESS", United Nations Taskforce for Social and Solidarity Economy (UNTFSSE), Ginebra, 2019.

https://knowledgehub.unsse.org/es/knowledge-hub/odd-dans-la-zone-ohada-deloutil-cooperatif-au-paradigme-ess-2/

HENRŸ, H.: "Public international cooperative law". In: International Handbook of Cooperative Law (coords. CRACOGNA D., FICI, A. \& HENRŸ, H.), Springer, Heidelberg, 2013, pp. 65-88.

DOI: http://dx.doi.org/10.1007/978-3-642-30129-2_2

HIEZ, D. \& TADJUDJE, W.: "Presentation of the new OHADA law on cooperatives", Revue internationale de l'économie sociale (RECMA), 2012.

http://www.recma.org/sites/default/files/new_ohada_cooperative_law.pdf

INTERNATIONAL LABOUR ORGANIZATION [ILO]: Promotion des coopératives, 89th session of the International Labor Conference, International Labor Organization (ILO), Ginebra, 2001.

https:/www.ilo.org/public/french/standards/relm/ilc/ilc89/pdf/rep-v-2.pdf

KAMDEM, I.F.: "Harmonisation, unification et uniformisation. Plaidoyer pour un discours affiné sur les moyens d'intégration juridique", Revue juridique Thémis (RJTUM), no 43(3), 2009, pp. 605-649.

https://ssl.editionsthemis.com/revue/article-4766-harmonisation-unification-et-uniformisation-plaidoyer-pour-un-discours-affine-sur-les-moyens-d-integration-juridique.html 
Harmonization (or rather Standardization) of Cooperative Law in the OHADA Zone...

(pp. 67-96)

MAMADOU, A.P.: "Information et sensibilisation des acteurs sur le mouvement coopératif”, Agence Centrafricaine de Presse (ACAP), Bangui, 2018.

https://www.acap.cf/Information-et-sensibilisation-des-acteurs-sur-le-mouvement-cooperatif_a9125.html

MINISTRY OF MINING AND GEOLOGY (CENTRAL AFRICAN REPUBLIC): Guide de procédure à l'usage des opérateurs du secteur minier, Government of the Central African Republic, Bangui, 2018. http://mines.gouv.cf/sites/default/ files/2018-12/GUIDE_PROCEDURE\%20A\%20L\%27USAGE\%20DES\%20 OPERATEURS\%20MINIERS.pdf

MÜNKNER, H.H.: "La loi coopérative, instrument de promotion des coopératives par l'Etat", Informations coopératives, ${ }^{\circ} 1,1973$, pp. 27-43.

MÜNKNER, H.H.: "Possibilities and Problems of Transformation of Local Village Groups into Pre-Cooperatives", Third World Legal Studies, no 1(12), 1982, pp. 174-192. http://scholar.valpo.edu/twls/vol1/iss1/12

MÜNKNER, H.H.: "Strengths and weaknesses of the co-operative movement in west Africa - conditions for its development", Terre et progrès, $n^{\circ} 71,1987$, pp. 16-18.

MÜNKNER, H.H.: "Cooperative audit". In: Principles of European Cooperative law (coords. FAJARDO GARCÍA, I.G., FICI, A., HENRŸ, H., HIEZ, D., MEIRA, D., MÜNKNER, H.H. \& SNAITH, I.), Intersentia, Cambridge, 2017, pp. $97-$ 118. DOI: https://doi.org/10.1017/9781780686073.006

TADJUDJE, W.: Le droit des coopératives et des mutuelles dans l'espace OHADA, Éditions Larcier, Bruselas, 2015.

TADJUDJE, W.: "L'accès durable des paysans à la terre : quel peut être l'apport des coopératives à la lutte contre l'accaparement des terres en Afrique?", Revue des mutations en Afrique, no 1(1), 2015, pp. 135-156. Handle: https://hdl.handle. net/10855/23259

TADJUDJE, W.: "Lévolution historique du droit des sociétés coopératives en Afrique". In: Droit des coopératives OHADA (coords. HIEZ, D. \& KENMOGNE SIMO, A.), Presses Universitaires d'Aix-Marseille (PUAM), Marsella, 2017, pp. 89-105.

TADJUDJE, W.: "Les enjeux de la définition de la société en droit OHADA", Revue de droit international et de droit comparé, no 95(2), 2018, pp. 283-300.

TADJUDJE, W.: "The East African Community's Cooperative regulation", International Journal of Cooperative Law (IJCL), no 1, 2018, pp. 148-164.

TADJUDJE, W.: "Les coopératives à Madagascar : quel équilibre entre attributions de l'État et développement du mouvement?", Révue internationale de l'economie sociale (RECMA), $\mathrm{n}^{\circ} 351,2019$, pp. 101-113. 
TADJUDJE, W.: Les conditions de l'efficacité des coopératives in Africa, Éditions Academia-EME, Louvain-la-Neuve, 2020.

TADJUDJE, W.: "Standardization of Cooperative law in Africa: A Comparative Analysis Between the OHADA Act Related to Cooperative Societies and the East Africa Community's Cooperative Societies Bill”, International Journal of Cooperative Law (IJCL), no 3, 2020, pp. 31-45.

TADJUDJE, W. (coord.): Le droit des coopératives en Afrique. Réflections sur l'Acte uniforme de l'OHADA, Éditions et Presses Universitaires de Reims (Épure), Reims, 2021. https://library.oapen.org/handle/20.500.12657/50848

TADJUDJE, W. \& LABI, C.: "Business Ethics in the OHADA Zone: Uniform Law, Uniform Ethics?". In: An Anthology of Ethics, (coord. FRENKEL, D.A.), Athens Institute for Education and Research (ATINER), Atenas, 2020, pp. 47-62. 